\title{
Organizational issues for integration of high- technology in new product development: framework proposal and case studies in Brazilian companies
}

\author{
Daniel Jugend, Sérgio Luis da Silva, Pedro Carlos Oprime \& Márcio Lopes \\ Pimenta
}

To cite this article: Daniel Jugend, Sérgio Luis da Silva, Pedro Carlos Oprime \& Márcio Lopes Pimenta (2015) Organizational issues for integration of high-technology in new product development: framework proposal and case studies in Brazilian companies, Innovation, 17:2, 217-231, DOI: 10.1080/14479338.2015.1013428

To link to this article: https://doi.org/10.1080/14479338.2015.1013428

曲 Published online: 27 Feb 2015.

Submit your article to this journal $₫$

山 Article views: 120

View Crossmark data $₫$

Citing articles: 3 View citing articles ¿ð 


\title{
Organizational issues for integration of high-technology in new product development: framework proposal and case studies in Brazilian companies
}

\author{
Daniel Jugend $^{\mathrm{a} *}$, Sérgio Luis da Silva ${ }^{\mathrm{b}}$, Pedro Carlos Oprime ${ }^{\mathrm{c}}$ and Márcio Lopes \\ Pimenta $^{\mathrm{d}}$ \\ ${ }^{a}$ Department of Production Engineering, São Paulo State University UNESP, Brazil; ${ }^{b}$ Information \\ Science Department, Federal University of São Carlos UFSCar, Brazil; ' ${ }^{c}$ Department of \\ Production Engineering, Federal University of São Carlos, Brazil; ${ }^{d}$ Faculty of Management and \\ Business, University of Uberlândia UFU, Brazil
}

(Received 8 May 2012; accepted 29 October 2014)

\begin{abstract}
Transference of new technological solutions requires integration between different functions and specialists involved in new product development (NPD). This paper examines management practices for integration between research and development (R\&D) with others involved in NPD and proposes a framework based on organizational variables. An organizational framework (ONPD) is constructed based on an analysis of the literature and evidence of case studies in Brazilian high-tech companies. It was observed that apart from the traditional use of cross-functional teams, these companies adopted integration practices including the use of employees from marketing with experience previously gained from $\mathrm{R} \& \mathrm{D}$, knowledge of the technology roadmap, and the project office structure. According to the interviewee perceptions, these initiatives may generate positive impacts on functional and organizational performance.
\end{abstract}

Keywords: functional integration; new product development; organizational frameworks; Brazilian high-tech companies

Studies in new product development (NPD) have emphasized the importance of functional departmental integration (Rubera, Ordanini, \& Calantone, 2012; Song \& Song, 2010). A study published by Product Development \& Management Association (PDMA), which gathered information from 416 executives in different industrial sectors involved with product development found that positive integration performance outcomes are associated with well-managed practices (Barczak, Griffin, \& Kahn, 2009).

A product is any object designed and produced to meet a commercial purpose and can incorporate various technologies (Murmann \& Frenken, 2006; Shulz, Clausing, Fricke, \& Negele, 2000). Notably, technological innovation requires combining knowledge from different internal functions and specialties to develop and launch products involving new knowledge for commercial applications (Brettel, Heinemann, Engelen, \& Neubauer, 2011; Burgelman, Mandique, \& Wheelwright, 2001).

Some studies indicate that NPD integration is problematized by managerial and departmental structures and functions, especially concerning marketing and research and development (R\&D) (Griffin \& Hauser, 1996; Rubera et al., 2012). Griffin and Hauser

\footnotetext{
*Corresponding author. Email: daniel@feb.unesp.br
} 
(1996) and Song and Song (2010) also observed the problem of cultural barriers, communication, and conflicting departmental objectives.

Many studies have analyzed integration in NPD (Brettel et al., 2011; Song \& Song, 2010). However, none were found that propose a framework based on a comprehensive approach to organizational variables. The objective of this paper is to propose a framework based on organizational variables to analyze NPD integration and examine how applicable this framework is to Brazilian high-tech companies. It proceeds with a literature review of mechanisms associated with proven NPD practices and constructs a framework to define the optimal organizational mechanisms that contribute to NPD, which we term ONPD. Secondly, using qualitative methods, we examine the extent to which the ONPD framework matches a sample of Brazilian companies already practicing NPD. Finally, the implications of ONPD in relation to industry practice is discussed.

\section{Literature review}

The subject of integration has been studied across many business organizations for several decades and the benefits and difficulties are well known. Integration generally depends on the existence of collaboration between the different roles within the company aimed at developing products that meet company objectives (Drejer, 2002; Lawrence \& Lorsch, 1973; Nobelius, 2004; Park, Lim, \& Birnbaum-More, 2009; Song \& Song, 2010). Moreover, integrated decisions improve the technical quality of new products and speeds the manufacturing processes within target budgets (Keller, 2001). A cost-leadership benefit accrues because individual departments maintain a macroorganizational focus when activities are integrated (Maltz \& Kohli, 2000). Integration can also generate positive impacts like mutual knowledge between people from different functions. Therefore, employees became more interested in issues related to the organization as a whole, and this phenomenon helps generate a positive esprit de corps (Narver \& Slater, 1990). Im and Workman (2004) found that cross-functional integration is one of the variables that define market orientation. These authors state that using this approach in NPD processes may improve the performance of new products, and generate positive impacts in sales, market share, return on investment (ROI), and profitability. Carbonell and Escudero (2010) also found that responsiveness to market - another market orientation variable - can speed the NPD processes because it provides a unified objective. Yannopoulos, Auh, and Menguc (2012) found that a proactive rather than reactive market orientation aided the success of new products in high-tech firms. Henke, Krachenberg, and Lyons (1993) argued that integration between internal functions provides better quality decision outcomes in comparison to decisions arrived at in isolation. Integration between internal functions related to NPD can also reduce time to market through shrinking the product development cycle (Sherman, Souder, \& Jenssen, 2000; Troy, Hirunyawipada, \& Paswan, 2008). Considering the broader view, Van Hoek and Chapman (2007) argued that alignment between R\&D and supply chain management enhances the adaption of logistics to meet strategic requirements. Moreover, Zacharia and Mentzer (2007) found that integrating these functions helps reduce negative impacts from trade-offs in future operations.

Griffin and Hauser (1996), Park et al. (2009), and Song and Song (2010) all highlighted the difficulties of enacting integration in circumstances of company growth, which results in complex management structures. Normally, company functions such as marketing, engineering, and $R \& D$ are specialist silos within their organizations. They often act in isolation with insufficient collaboration, communication, or sharing of knowledge with 
other departments. Clausing (1994), Griffin and Hauser (1996), and Maltz, Souder, and Kumar (2001) observed that problems associated with integration between these departments arise from competition between engineering, marketing, and R\&D.

Turning now to the mechanisms that enhance NPD, the literature identifies four organizational mechanisms that can overcome integration issues and these mechanisms provide the basis of our proposed ONPD framework. These mechanisms are presented in Table 1.

Maltz et al. (2001), Leal-Egaña (2006), Love and Roper (2009) and Park et al. (2009) proposed that the use of cross-functional teams can, with good managerial practice, increase the transference of knowledge to achieve collaboration and interaction. This mechanism may minimize problems resulting from cultural barriers between departments involved in NPD. Cross-functional teams can intensify the sharing of knowledge by assembling teams with different specialists involved with NPD (Calabrese, 1997; Katz \& Allen, 1997). Therefore, the first mechanism of the proposed ONPD framework is the establishment of cross-functional teams.

Souder, Buisson, and Garret (1997), Maltz et al. (2001) and Brettel et al. (2011) recognized that it is beneficial for R\&D managers to participate in market research with marketing personnel and meet clients. According to Brem and Voight (2009), this practice permits $R \& D$ to receive feedback directly from the market, without filtering by marketing. It has the potential to integrate insights of various specialists regarding individual client needs and indicate the scope for future products and technologies. Sherman, Berkowitz, and Souder (2005), and Becker and Lillemark (2006) highlighted that integration between $R \& D$ and marketing generates knowledge sharing and facilitates products that better meet market needs with efficient time to market. Therefore, the second mechanism of the proposed ONPD framework is participation of R\&D personnel in marketing activities.

Pinto, Pinto, and Prescott (1993), Maltz et al. (2001), Leenders and Wierenga (2002), and Eppinger and Chitkara (2006) noted that physical distance can inhibit

Table 1. Publications on integration of new product development.

\begin{tabular}{|c|c|}
\hline Category & Publication \\
\hline Cross-functional teams & $\begin{array}{l}\text { Pinto, Pinto, and Prescott (1993); Katz and Allen (1997); } \\
\text { Calabrese (1997); Maltz, Souder, and Kumar (2001); } \\
\text { Leal-Egaña (2006); Love and Roper (2009); Park, Lim } \\
\text { and Birnbaum-More (2009); Song and Song (2010) }\end{array}$ \\
\hline $\begin{array}{l}\text { Participation of R\&D personnel in } \\
\text { market research }\end{array}$ & $\begin{array}{l}\text { Roussel, Saad and Bohlin (1992); Souder, Buisson, and } \\
\text { Garret (1997); Maltz, Souder, and Kumar (2001); Brem } \\
\text { and Voight (2009); Brettel et al. (2011) }\end{array}$ \\
\hline Physical proximity & $\begin{array}{l}\text { Pinto, Pinto and Prescott (1993); Lee, Lee, and Souder } \\
\text { (2000); Maltz, Souder, and Kumar (2001); Leenders and } \\
\text { Wierenga (2002); Eppinger and Chitkara (2006) }\end{array}$ \\
\hline $\begin{array}{l}\text { Project leaders with both technical } \\
\text { and managerial capabilities }\end{array}$ & $\begin{array}{l}\text { Eldred and McGrath (1997); Kim, Min, and Cha (1999); } \\
\text { Toledo et al. (2007); Gumusluoglu and Ilsev (2009); } \\
\text { Kelley and Lee (2010) }\end{array}$ \\
\hline $\begin{array}{l}\text { Positive impacts of integration on } \\
\text { NPD }\end{array}$ & $\begin{array}{l}\text { Narver and Slater (1990); Henke et al. (1993); Maltz and } \\
\text { Kohli (2000); Sherman, Souder, and Jenssen (2000); } \\
\text { Keller (2001); Im and Workman (2004); Sherman, } \\
\text { Berkowitz, and Souder (2005); Becker and Lillemark } \\
\text { (2006); van Hoek and Chapman (2007); Zacharia and } \\
\text { Mentzer (2007); Troy et al. (2008); Carbonell and } \\
\text { Escudero (2010); Yannopoulos et al. (2012) }\end{array}$ \\
\hline
\end{tabular}


integration between functional roles and hinder NPD. The authors noted that, as a result of face-to-face interaction, a greater degree of integration between functional roles occurred when they were co-located. The third proposed ONPD mechanism, therefore, is that co-localization be adopted to strengthen integration across NPD departments.

Studies by Eldred and McGrath (1997), Kim, Min, and Cha (1999), Gumusluoglu and Ilsev (2009), and Kelley and Lee (2010), highlighted that project leaders with both technical and managerial capabilities can enhance integration. Leaders with this profile can bring managerial clarity to their technical roles while informing their managerial decisions with technical considerations and possibilities. This can be beneficial in establishing a consensus between different divisions and specialists involved in NPD. Project leaders with technical and managerial skills are therefore the fourth mechanism of ONPD required to enhance NPD integration.

\section{Research methodology}

With the objective of testing the proposed ONPD framework and identifying distinctive features of R\&D and NPD in Brazilian companies, a qualitative research approach was adopted. Yin (2005) has found that case studies provide a deeper analysis of a relatively small sample and can result in a broader understanding of the target research phenomena. The case study method is a well-accepted research strategy in innovation management in Brazilian companies (Pereira \& Plonski, 2009; Silvestre \& Dacol, 2009). However, studies of NPD integration in Brazilian companies are not available in the literature. To fill this gap and identify similarities and differences between various sampled organizations in terms of framework practices, five case studies were conducted.

\section{Company profiles}

Table 2 provides a profile of the companies participating in the case studies. The participating companies were assigned the following names: A, B, C, D, and E. Selection was made using intentional sampling (Yin, 2005). Emblematic cases of high-tech companies were identified from data provided by Brazilian researchers of innovation management and from specialists who work at Brazilian high-tech companies. From this initial sampling, the following criterion was used for selection: medium- or large-sized Brazilian companies spending at least $6 \%$ of their revenues on innovation. Comparing this spending with results from industrial technology innovation research (PINTEC) for 2008, conducted by the Brazilian Institute of Geography and Statistics (IBGE) and based on the Oslo manual, it was confirmed that the Brazilian companies studied are among leading investors in product innovation.

Additionally, cases from companies that operate in different contexts - that is, in terms of products, clients, suppliers, technologies, and locations - were used to strengthen the validity of the study (Gibbert \& Ruigrok, 2010). Two of the firms were industrial automation companies, one was a medical and hospital equipment company, one was an optics specialist, and the final represented medical-dentistry equipment, military, aerospace technologies, and fine films. Criteria employed by the Brazilian Support Services to Small and Micro companies (SEBRAE) were used to define company size. Medium-sized companies are those with 100-499 employees and large companies have more than 500 employees. Semi-structured interviews were carried out using an open and closed questionnaire. The questions were compiled with the objective of analyzing the four dimensions of the proposed ONPD framework, plus questions to elicit the 


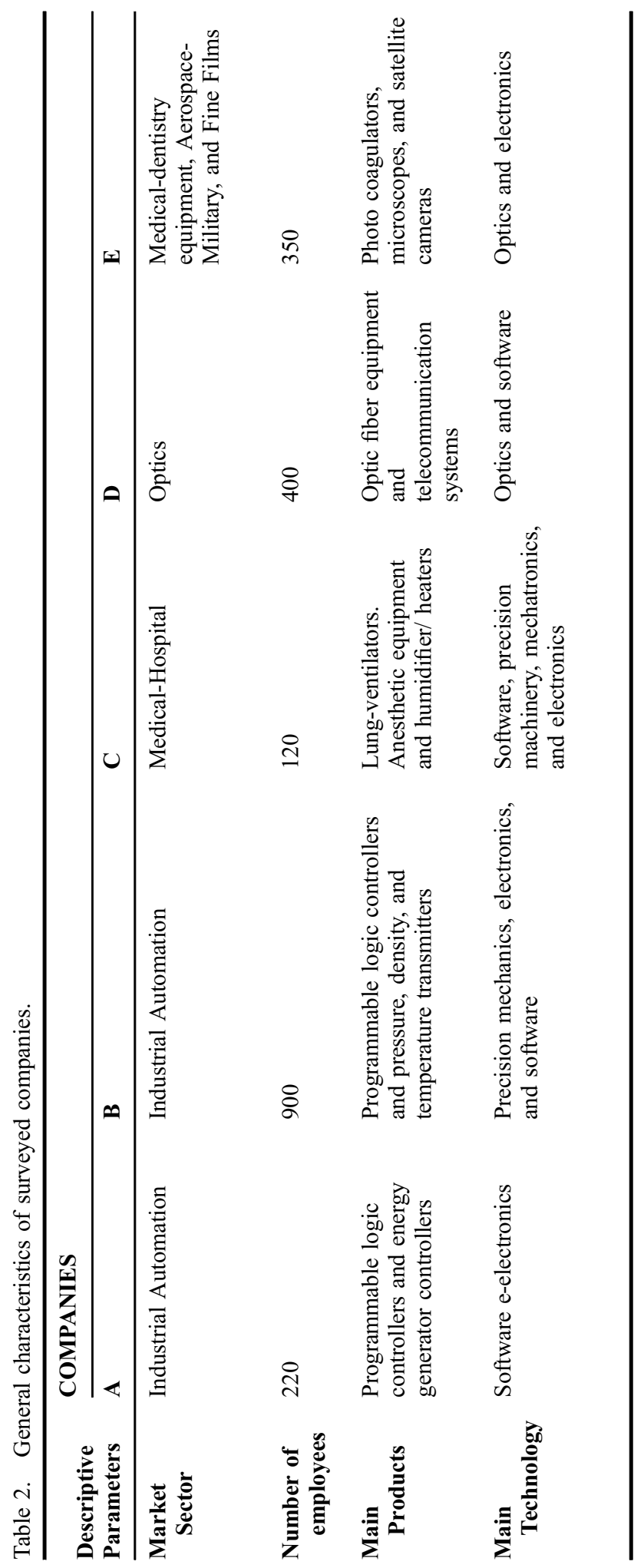




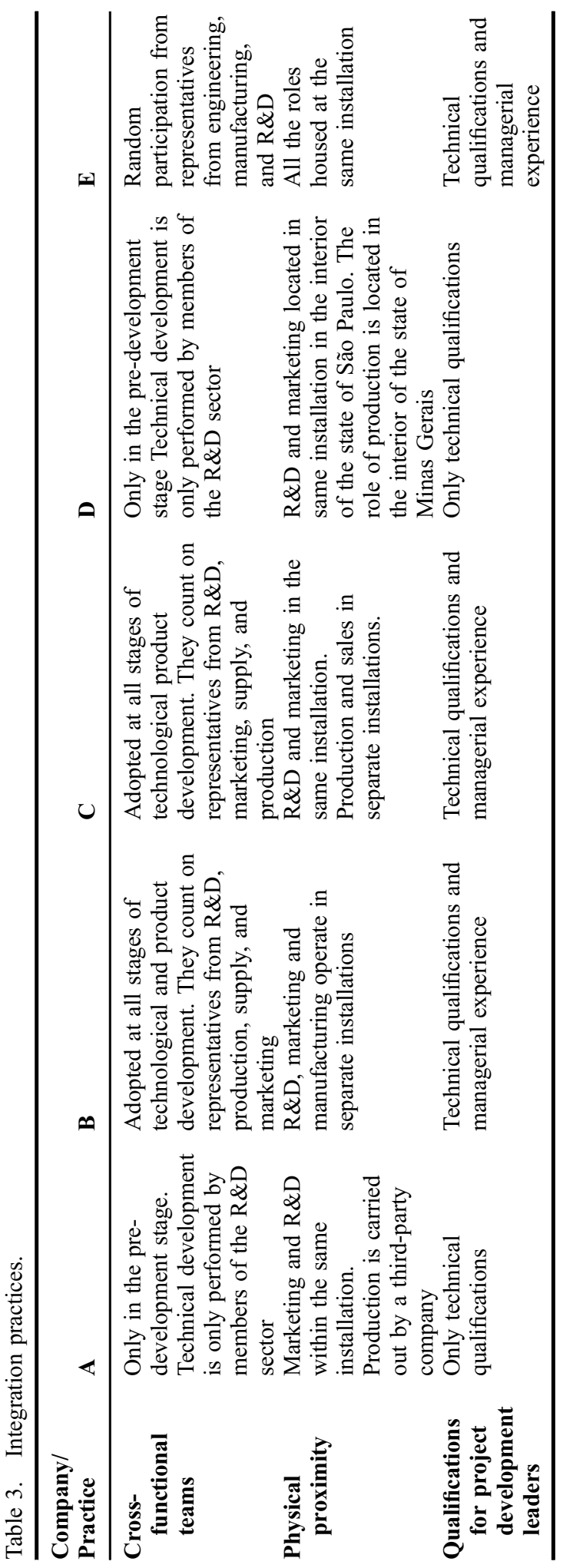


perceived benefits of integrated NPD initiatives. All companies were visited by the researchers, and different specialists involved in R\&D-NPD integration were interviewed, including directors, engineers, managers, and coordinators from R\&D, marketing, industrial planning, and production control.

\section{Results}

Table 3 summarizes the extent to which companies manage NPD according to the four mechanisms defined by the proposed ONPD framework: cross-functional teams; participation of R\&D in market research; physical proximity (co-location); and project leaders with both technical and managerial capabilities.

\section{Cross-functional teams}

Companies $\mathrm{B}$ and $\mathrm{C}$ have institutional policies regarding the adoption of cross-functional teams that work throughout the NPD process. The product functions of Company $\mathrm{B}$ involve a team of coordinators who work during the mornings with the development team and afternoons in the company's factories. This practice was adopted by the company to strengthen relations between $R \& D$ and production and assist with information gathering and knowledge sharing. As the head of R\&D of Company B explained:

This daily contact improves the knowledge of people who work in development about manufacturing's constraints and opportunities, and, at the same time, the understanding of the manufacturing people about development possibilities.

On the other hand, in companies A and D, the presence of cross-functional teams is stronger at the strategic planning and pre-development stages, rather than the factory floor. Normally, these companies would form groups with representatives from R\&D, manufacturing, marketing, and supplies to evaluate and approve development projects for new products and technologies. However, after deliberations regarding the products and technologies to be developed, the rest of the work was supervised by representatives from R\&D. As a Director of Company D observed:

People from marketing are involved in decisions about what products we have to develop and $[\ldots]$ the characteristics of those products. However, in the technical development of the product project, only R\&D, manufacturing, and purchasing people join. Only when the prototype is done, people from marketing get back to the project. At this point, marketing people better [understand] the developed product and get the sales efforts started.

These results support research by Olson, Orville, Ruekert, and Bonner (2001), who verified that integration between representatives from technical functions and management departments is normally intense during pre-development stages. In Company E, participation of engineering representatives in product development projects that relied on development and transference of technology did not occur systematically. Their participation was related to the level of importance assigned to the project as well as the availability of personnel for project innovation. For example, integration between R\&D and engineering was subject to company exigencies and varied according to the project being developed. There was a high level of collaboration and interaction between manufacturing staff, but this was limited to manufacturing of new products. 
The ability of R\&D to meet marketing deadlines was a problem reported by companies A, C, and E. These companies emphasized that this problem occurred due to conflicting goals and priorities within respective divisions, and they implemented NPD processes to resolve these problems.

Regarding the participation of R\&D personnel in market research, unlike the recommendations from the literature (Brettel et al., 2011; Maltz et al., 2001; Souder et al., 1997), none of the sampled companies found it necessary to adopt this practice. The marketing and customer support teams, that is installation and technical assistance, provided customer feedback. The sample companies did not employ specialists in product definition, new market opportunities, or the development of new technologies for integrating marketing activities related to client contact and market research.

Although there is a necessity to translate market needs obtained by marketing into technical development work for R\&D, respondents in the interviews did not highlight this fact as a problem for integration. Marketing professionals were aware of the technical aspects and requirements of the products, which tended to foster a mutual understanding between specialists of development requirements and opportunities. Companies $\mathrm{B}, \mathrm{C}$, and $\mathrm{D}$ indicated that the acquisition of this technical knowledge should be accumulated in their marketing departments, especially by those who are graduates of technical courses or have technical experience. As the CEO of Company D explained:

As our product meets demands from other industries, particularly in the telecommunications sector, our product is very specific, and to sell it, as well as to figure out the market, it is necessary to have a person who knows the aspects of the product technology. Therefore, our marketing is composed of undergraduate people who also have a technical experience.

\section{Physical proximity}

In terms of physical proximity, Table 3 shows that the occurrence of geographical separation between departments involved with product development and technology was common, with only Company $\mathrm{E}$ having $\mathrm{R} \& \mathrm{D}$, marketing, and manufacturing in the same location. Physical proximity between R\&D and marketing (Companies A, B, and $\mathrm{C}$ ), as well as the physical distance between $\mathrm{R} \& \mathrm{D}$ and production and sales were noted (A, C, and D).

Observations from the relevant literature regard physical distance as a constraint of interaction and subsequent integration in the development of products (Leenders \& Wierenga, 2002; Maltz et al., 2001). The frustration caused by the physical separation between departments involved in NPD was mentioned by the R\&D manager from Company $\mathrm{C}$ as follows:

We have difficulties meeting with manufacturing because the plant is far from the engineering and the R\&D, and this inhibits integration. Aiming to improve the communication, among different specialists, the company is building a new facility to group these departments and manufacturing at the same location.

Regarding co-localization, the head of R\&D from Company B explained the situation between his area and marketing in the following terms:

When I need to talk to someone in marketing, I have to call and book a meeting, and sometimes it's not possible to do. On the other hand, when I need to talk to people from $\mathrm{R} \& \mathrm{D}$, I simply go to their desk. 
With the aim of minimizing integration problems due to distance, Company D, which concentrated their product development and technology activities in São Paulo, continuously sent their R\&D teams to the factory, located approximately $233 \mathrm{~km}$ away. To reduce this problem, the company adopted virtual mechanisms to bring these specialists together. As the CEO explained:

In order to take taxes advantages, offered by government, we transferred manufacturing activities to another city. To reduce communication problems, due to the physical distance between R\&D and manufacturing, we started to use virtual communication mechanisms like videoconferencing and Skype.

In the evaluation of the respondent comments, there was a general consensus with the recommendations of Eppinger and Chitkara (2006) regarding the adoption of information technology. This resulted in improving the transference of knowledge (mainly tacit) for product development work, which depended on the integration of local specialists based in different geographical regions.

However, companies disagreed regarding the benefits of physical proximity of R\&D for NPD. Despite general agreement on the rationalization of functional locations, Company A indicated the creative potential of $R \& D$ was substantially reduced due to centralization. This occurred because R\&D is limited by rigid working hours, administrative problems, and informal conversations that were subject to management scrutiny. As the Software Development Manager observed:

When the R\&D Center was in a separate place, we had flexible working hours and could spend a lot of time talking informally about technical solutions, and about new products and technologies. However, now that we are at the same building as the rest of company, we have to follow normal working hours [and are] subjected to traditional work supervision.

\section{Project leaders}

Table 3 shows that project leaders in all sample companies had appropriate qualifications in engineering and technology. Managerial expertise reported by project leaders in companies $\mathrm{B}, \mathrm{C}$, and $\mathrm{E}$ was accumulated from project experience rather than formal qualifications in management. Past experience assisted these leaders in delivering a satisfactory level of integration between the different specialists involved in NPD. Concerning this positive aspect of technical experience in integration, the Product Manager of Company $\mathrm{C}$ reported that:

As the sales managers are experienced R\&D and engineering, they know technical aspects of the products and they can precisely communicate market needs to us who work in development.

Furthermore, as Company E Project Management Officer explained:

As our head of R\&D has been in the company since it started, he knows the technical aspects very well, and has a deep knowledge about the market [and how to] respond to customer needs. He leads the most complex development projects and can figure out what is required from all departments involved in the project.

Brazilian research into NPD project management skills, including Toledo et al. (2007) and Jugend and Silva (2010), observed that lack of managerial qualifications, as was the 
Table 4. Positive impacts of integration in NPD processes and respective mechanisms.

\begin{tabular}{|c|c|c|c|}
\hline Companies & Related mechanism & $\begin{array}{l}\text { Impacts on functional } \\
\text { and organizational } \\
\text { performance }\end{array}$ & $\begin{array}{l}\text { Impacts on inter- } \\
\text { functional integration }\end{array}$ \\
\hline $\mathrm{B}$ and $\mathrm{C}$ & Cross-functional teams & $\begin{array}{l}\text { Accelerate the work to } \\
\text { fulfill NPD activities to } \\
\text { scheduled time } \\
\text { Accelerates time to market }\end{array}$ & $\begin{array}{l}\text { Strengthens the meetings } \\
\text { between functions' } \\
\text { representatives } \\
\text { Helps with the sharing of } \\
\text { information }\end{array}$ \\
\hline A and D & Cross-functional teams & $\begin{array}{l}\text { Provides more effective } \\
\text { decision-making in the } \\
\text { earlier stages of NPD }\end{array}$ & \\
\hline $\mathrm{D}$ & $\begin{array}{l}\text { Physical proximity } \\
\text { (adoption of virtual } \\
\text { technology between } \\
\text { plants distant from each } \\
\text { other) }\end{array}$ & $\begin{array}{l}\text { Improves the standard of } \\
\text { communication in the NPD } \\
\text { process }\end{array}$ & $\begin{array}{l}\text { Increases integration } \\
\text { between } R \& D \text { and } \\
\text { production personnel }\end{array}$ \\
\hline A and D & $\begin{array}{l}\text { Project leaders with } \\
\text { technical and managerial } \\
\text { capabilities }\end{array}$ & $\begin{array}{l}\text { Improves NPD } \\
\text { performance due to the } \\
\text { knowledge sharing } \\
\text { between technicians and } \\
\text { managers }\end{array}$ & \\
\hline $\begin{array}{l}\mathrm{A}, \mathrm{C} \text {, and } \\
\mathrm{E}\end{array}$ & $\begin{array}{l}\text { Participation of } \mathrm{R} \& \mathrm{D} \\
\text { personnel in market } \\
\text { research }\end{array}$ & $\begin{array}{l}\text { Helps to synchronize the } \\
\text { development period } \\
\text { expected by the marketing } \\
\text { department, accelerating } \\
\text { time to market }\end{array}$ & $\begin{array}{l}\text { Increases information } \\
\text { sharing between R\&D and } \\
\text { marketing, intensifying the } \\
\text { integration between these } \\
\text { functions }\end{array}$ \\
\hline
\end{tabular}

case for companies $\mathrm{A}$ and $\mathrm{D}$, constrain interactions between marketing and R\&D. Representatives from Companies A and D stated that, given their exclusive technical profiles, project leaders had difficulty in communicating efficiently with marketing. These companies also reported this lack of expertise could reduce the performance of NPD. For the R\&D Coordinator from Company A, this was an issue that needed to be redressed:

To improve the managerial capacity of managers and coordinators, the company has been encouraging their employees to study graduate courses in the management area.

\section{Positive impacts of physical and cross-functional integration}

Practices conducive to integration between $R \& D$ and other divisions involved in NPD observed from the case studies are set out in Table 4 . In regard to the benefits of crossfunctional teams, companies $\mathrm{B}$ and $\mathrm{C}$ reported improved communication and speed to market, while companies $\mathrm{A}$ and $\mathrm{D}$ noted an improvement in decision-making in the early stages of $\mathrm{R} \& \mathrm{D}$. Company $\mathrm{D}$ claimed that physical proximity, actual or virtual, improved integration and knowledge sharing across departments. Companies A, C, and E found that participation of R\&D staff in market research synchronized NPD, the sharing of information, and improved time to market. These results confirm previous studies concerning integration in NPD including, Maltz et al. (2001), Leenders and Wierenga (2002), Eppinger and Chitkara (2006) and Park et al. (2009).

With regard to the practical application of specific integration practices, the technological development projects carried out by Company $\mathrm{B}$ achieved improved results 
because their leaders meet with other product development managers to discuss the cross-application of new technologies in development. This practice was mostly beneficial for integration efforts because, apart from generating improvements for the crossapplication of technologies, it intensified knowledge sharing work by R\&D with other parties. When scheduling or operational problems occurred, Company B took a proactive task-force approach where a director was appointed to accelerate development and meet the scheduled timeframe.

With the objective of aligning understanding between the technical functions and management personnel, the R\&D staff of Company $\mathrm{C}$ made presentations to marketing to explain the technical specifications of the product and/or technologies. They provided materials for discussion that increased information sharing between R\&D and marketing, thereby intensifying integration.

Company E formed a project office structure to integrate the technical functions involved with product development. To achieve this, in addition to intensifying the institutionalization of mechanisms including inter-functional meetings and dialogue, the project office explored the implementation of software to facilitate interaction between department functions.

Among formal mechanisms for stimulating integration, Companies $\mathrm{A}, \mathrm{B}$, and $\mathrm{C}$ mentioned their intention to adopt a technology roadmap (TRM). Two reasons were given for this. First, Brazilian promotion agencies have begun to demand technological maps as part of their criteria for financing technology innovation projects, especially Financier of Studies and Projects, (FINEP) and the National Bank of Economic and Social Development (BNDES). The second reason was related to the influence of multinationals in the electronic sector that already apply TRM benchmarking.

\section{Discussion}

Of the four mechanisms defined by the ONPD framework, participation by R\&D personnel in marketing and physical proximity as co-location did not feature in the NPD practices of the five companies studied. These variations in NPD practice can be explained by the fact that, in the first instance, the marketing managers are former $R \& D$ employees. Therefore, direct participation of $R \& D$ personnel in marketing activities is not required.

Unlike the findings stated in the literature (Brettel et al., 2011; Maltz et al., 2001; Souder et al., 1997), companies not involving their R\&D personnel in market research activities had already enhanced the marketing function by involving engineers who had previous experience in R\&D. By facilitating the translation of market data for technical work as well as requirements for product development, this practice demonstrated the benefits of integrated technical and managerial roles involved with development work.

On the other hand, daily allocations of production teams to the R\&D department intensified the integration process between these functions by strengthening face-to-face meetings between the specialists through geographical proximity, as was the case with Company B. A similar practice could be applied by combining marketing teams with the R\&D department. Considering the proposed ONPD framework, this is a practice that can be enhanced by physical or virtual proximity and deployment of cross-functional teams.

Meetings between managers of different product groups and technologies regarding information sharing, as adopted by Company B, can be an efficient mechanism for knowledge transfer. It can also benefit application and transference of new technologies 
for different products, which can thereby improve NPD performance by reducing the time to market and the cross-application of newly developed technologies.

In relation to co-localization, Company A underscored that although this practice favors integration, it can jeopardize the creative potential of R\&D personnel who tend to be subjected to company routines. Furthermore, problems encountered by lack of physical co-location can be overcome by virtual technologies, as exemplified by Company D. With the objective of increasing integration among these areas, Company D intensified the application of mechanisms for the transfer of technical information by the internet, creating virtual cross-functional teams with representatives for these roles.

It is necessary to recognize that unlike many large and/or multinational companies with a technological base, the companies in this study had R\&D centers exclusively dedicated to identifying, developing, and implementing new technologies. However, none of the surveyed companies used their R\&D resources to develop future technologies unless they had an immediate commercial interest associated with a particular product. This is a limitation of the field check for the proposed ONPD framework, which should not be applied to all high-tech companies. Future studies should evaluate this framework at companies with centers dedicated only to formal $R \& D$ activities in isolation.

Another limitation of this research was its exclusive focus on organizational elements used to investigate the phenomena of integration. Apart from the focus on technological information, other managerial methods such as quality function deployment (QFD), stage gates, and value engineering - all of which are recognized methods for stimulating integration between specialists and functions involved with product technology development - were not explored. Future studies about NPD and innovative management could investigate integration from these viewpoints. Future studies could also make quantitative analyses at companies with $R \& D$ areas that continuously develop products by analyzing correlations between the mechanisms in this framework for improving integration and NPD performance.

Finally, future research may further analyze the elements of the ONPD framework concerning its ability to provide the impacts perceived by the interviewees. Quantitative studies of correlations can help develop scales to evaluate firms' characteristics and their impacts on NPD success and performance.

\section{Conclusion}

This paper contributes to an understanding of best practice NPD by presenting an ONPD framework comprised of organizational mechanisms for analyzing and improving integration in new product projects, and demonstrating the extent to which these mechanisms are applied in a sample of Brazilian high-tech companies. It showed that the benefits of an organizational approach to NPD can lower cost, increase speed to market, and facilitate market leadership. However, the ways these mechanisms can be deployed by companies vary, and further qualitative and quantitative research is indicated as models of best practice NPD will continue to evolve over time and across various industry sectors.

The application of the practices identified in this study can help integrate different specialist roles, which frequently face challenges in obtaining a common understanding regarding the development of technical products. These difficulties tend to hamper various activities related to product development of high-tech content such as the translation of a client's technical product needs, which can consequently prejudice the development of those products and associated technological innovations. 
The surveyed companies had a competitive differentiator within their organizational structures focusing on technical development activities. All companies that integrated similarities across those activities typically associated them with engineering and R\&D divisions. This type of structure resulted in greater agility in product development, which can provide a competitive advantage.

\section{Acknowledgments}

We would like to thank the reviewers of this article for their invaluable comments and suggestions.

\section{References}

Barczak, G., Griffin, A., \& Kahn, K. B. (2009). Perspective: Trends and drivers of success in NPD practices. Journal of Product Innovation Management, 26, 3-23.

Becker, M. C., \& Lillemark, M. (2006). Marketing/R\&D integration in the pharmaceutical industry. Research Policy, 35, 105-120.

Brem, A., \& Voight, K. (2009). Integration of market pull and technology push in the corporate front end and innovation management - insights from the Germany software industry. Technovation, 29, 351-367.

Brettel, M., Heinemann, F., Engelen, A., \& Neubauer, S. (2011). Cross-functional integration of R\&D, marketing, and manufacturing in radical and incremental product innovations and its effects on project effectiveness and efficiency. The Journal of Product Innovation Management, 28, 251-269.

Burgelman, R. A., Mandique, M. A., \& Wheelwright, S. C. (2001). Strategic management of technology and innovation (3rd ed.). Singapore: McGraw-Hill Book.

Calabrese, G. (1997). Communication and co-operation in product development: A case study of the European car producer. $R \& D$ Management, 27, 239-252.

Carbonell, P., \& Escudero, R. A. I. (2010). The effect of market orientation on innovation speed and new product performance. Journal of Business \& Industrial Marketing, 25, 501-513.

Clausing, D. (1994). Total quality development: A step-by-step guide to world-class concurrent engineering. New York, NY: Asme.

Drejer, A. (2002). Integrating product and technology development. International Journal of Technology Management, 24, 124-142.

Eldred, E. W., \& McGrath, M. E. (1997). Commercializing new technologies - II. Research Technology Management, 40, 29-33.

Eppinger, S. D., \& Chitkara, A. R. (2006). The practice of global product development. MIT Sloan Management Review, 27, 1-11.

Gibbert, M., \& Ruigrok, W. (2010). The "what" and "how" of case study rigor: Three strategies based on published work. Organizational Research Methods, 13, 710-737.

Griffin, A., \& Hauser, J. R. (1996). Integrating R\&D and marketing: A review and analysis of the literature. Journal of Product Innovation Management, 13, 191-215.

Gumusluoglu, L., \& Ilsev, A. (2009). Transformational leadership and organizational innovation: The roles of internal and external support for innovation. The Journal of Product Innovation Management, 26, 264-277.

Henke, J. W., Krachenberg, R., \& Lyons, T. F. (1993). Cross-functional teams: Good concept, poor implementation. Journal of Product Innovation Management, 10, 216-229.

Im, S., \& Workman, J. P., Jr. (2004). Market orientation, creativity, and new product performance high-technology firms. Journal of Marketing, 68, 114-132.

Jugend, D., \& Silva, S. L. (2010). Práticas de gestão que influenciam o sucesso de novos produtos em empresas de base tecnológica [Management practices influencing new product success in technology-based companies]. Revista Produção, 20, 335-346.

Katz, R., \& Allen, T. J. (1997). Organizational issues in the introduction of new technologies. In R. Katz (Ed.), The human side of managing technological innovation (pp. 384-410). Oxford: Oxford University Press. 
Keller, R. (2001). Cross-functional project groups in research and new product development: Diversity, communication, job stress, and outcomes. Academy of Management Journal, 44, $547-555$.

Kelley, D., \& Lee, H. (2010). Managing innovation champions: The impact of project characteristics on direct manager role. Journal of Product Innovation Management, 27, 1007-1019.

Kim, Y., Min, B., \& Cha, J. (1999). The roles of R\&D team leaders in Korea: A contingent approach. $R \& D$ Management, 29, 153-165.

Lawrence, P. R., \& Lorsch, J. W. (1973). As empresas e o ambiente: diferenciação e integração administrativas [Organization and environment: Managing differentiation and integration]. Petrópolis: Vozes.

Leal-Egaña, A. (2006). Multidisciplinary teams: The next step in the science. Journal of Technology Management \& Innovation, 1, 21-26.

Lee, J., Lee, J., \& Souder, W. E. (2000). Differences of organizational characteristics in new product development: Cross-cultural comparison of Korea and US. Technovation, 20, 497-508.

Leenders, M. A. A. M., \& Wierenga, B. (2002). The effectiveness of different mechanisms for integrating marketing and R\&D. The Journal of Product Innovation Management, 19, 305-317.

Love, J. H., \& Roper, S. (2009). Organization innovation: Complementarities between crossfunctional teams. Technovation, 29, 192-203.

Maltz, E., \& Kohli, A. K. (2000). Reducing marketing's conflict with other functions: The differential effects of integrating mechanisms. Journal of Academy of Marketing Science, 28, 479-492.

Maltz, E., Souder, W. E., \& Kumar, A. A. (2001). Influencing R\&D/marketing integration and the use of market information by R\&D managers intended and unintended effects of managerial actions. Journal of Business Research, 52, 69-82.

Murmann, J. P., \& Frenken, K. (2006). Toward a systematic framework to research on dominant designs, technological innovations, and industrial change. Research Policy, 35, 925-952.

Narver, J. C., \& Slater, S. F. (1990). The effect of a market orientation on business profitability. Journal of Marketing, 54, 20-35.

Nobelius, D. (2004). Linking product development to applied research: Transfer experiences from an automotive company. Technovation, 24, 321-334.

Olson, E. M., Orville, C. W., Ruekert, R. W., \& Bonner, J. B. (2001). Patterns of cooperation during new product development among marketing, operations and R\&D: Implications for project performance. Journal of Product Innovation Management, 18, 258-271.

Park, M. H., Lim, J. W., \& Birnbaum-More, P. H. (2009). The effect of multiknowledge individuals on performance in cross-functional new product development teams. The Journal of Product Innovation Management, 26, 89-96.

Pereira, L., \& Plonski, G. A. (2009). Shedding light on technological development in Brazil. Technovation, 29, 451-464.

Pinto, M. B., Pinto, J. K., \& Prescott, J. E. (1993). Antecedents and consequences of project team cross-functional cooperation. Management Science, 39, 1281-1297.

Roussel, P. A., Saad, K. N., \& Bohlin, N. (1992). Pesquisa \& Desenvolvimento: como integrar $P \& D$ ao plano estratégico e operacional das empresas como fator de produtividade e competitividade [Third generation R\&D: Managing the link to corporate strategy]. São Paulo: Makron Books.

Rubera, G., Ordanini, A., \& Calantone, R. (2012). Whether to integrate R\&D and marketing: The effect of firm competence. The Journal of Product Innovation Management, 29, 766-783.

Sherman, J. D., Berkowitz, D., \& Souder, W. E. (2005). New product development performance and the interaction of cross-functional integration and knowledge management. Journal of Product Innovation Management, 22, 399-411.

Sherman, J. D., Souder, W. E., \& Jenssen, S. A. (2000). Differential effects of the primary forms of cross functional integration on product development cycle time. Journal of Product Innovation Management, 17, 257-267.

Shulz, A. P., Clausing, D., Fricke, E., \& Negele, H. (2000). Development and integration of winning technologies as key to competitive advantage. Systems Engineering, 3, 180-211.

Silvestre, B. S., \& Dacol, P. R. T. (2009). Geographical proximity and innovation: Evidences from the campos basin oil \& gas industrial agglomeration-Brazil. Technovation, 29, 546-561.

Song, L. Z., \& Song, M. (2010). The role of information technologies in enhancing R\&D-marketing integration: An empirical investigation. Journal of Product Innovation Management, 27, 382-401. 
Souder, W. E., Buisson, D., \& Garret, T. (1997). Success through customer-driven new product development: A comparison of US and New Zealand small entrepreneurial high technology firms. Journal of Product Innovation Management, 14, 459-472.

Toledo, J. C., Silva, S. L., Paula, S. M., Mendes, G. H. S., and Jugend, D. (2007). "Factors influencing new products success in small Brazilian medical and hospital equipment firms." In Loureiro G., and Curran C. (Org.) Complex systems concurrent engineering: Collaboration, technology innovation and sustainability Vol. 1 1st edn, pp. 657-664. Springer Verlag, London.

Troy, L. C., Hirunyawipada, T., \& Paswan, A. K. (2008). Cross-functional integration and new product success: An empirical investigation of the findings. Journal of Marketing, 72, 132-146.

van Hoek, R., \& Chapman, P. (2007). How to move supply chain beyond cleaning up after new product development. Supply Chain Management, 12, 239-244.

Yannopoulos, P., Auh, S., \& Menguc, B. (2012). Achieving fit between learning and market orientation: Implications for new product performance. Journal of Product Innovation Management, 29, 531-545.

Yin, R. K. (2005). Estudo de caso: planejamentos e métodos [Case study research: Design and methods] (3rd ed.). Porto Alegre: Bookman.

Zacharia, Z. G., \& Mentzer, J. T. (2007). The role of logistics in new product development. Journal of Business Logistics, 28, 83-110. 